\title{
Effects of Metal Oxides on Carbonation and Coking of High-Salinity Organic Wastewater
}

\author{
Jumei Ye, ${ }^{1}$ Zhuang Li ${ }^{1},{ }^{1}$ Chongcong $\mathrm{Li}^{2}{ }^{2}$ Tianya $\mathrm{Li}^{3}{ }^{3}$ Ziqiao Gao, ${ }^{4}$ and Hui Dong ${ }^{5}$ \\ ${ }^{1}$ College of Petroleum Engineering, Liaoning Shihua University, Fushun, Liaoning 113001, China \\ ${ }^{2}$ School of Energy and Power Engineering, Dalian University of Technology, China \\ ${ }^{3}$ College of Chemistry and Chemical Engineering, Liaoning Normal University, China \\ ${ }^{4}$ China Liaohe Petroleum Engineering Co., Ltd.(LPE), China \\ ${ }^{5}$ SEPA Key Laboratory on Eco-Industry, Northeastern University, China \\ Correspondence should be addressed to Zhuang Li; lizhuang@lnpu.edu.cn
}

Received 6 October 2020; Revised 23 November 2020; Accepted 30 November 2020; Published 11 December 2020

Academic Editor: Jason L. Pitters

Copyright (C) 2020 Jumei Ye et al. This is an open access article distributed under the Creative Commons Attribution License, which permits unrestricted use, distribution, and reproduction in any medium, provided the original work is properly cited.

\begin{abstract}
Slag is difficult to treat quantitatively due to the formation of a molten mixture in the carbonization process of high-salinity organic wastewater. Thus, aiming at solving this difficulty, the effects of metal oxide additives, additive ratio, furnace burden ratio, and carbonization temperature on the carbonization and coking of high-salinity organic wastewater are systematically analyzed. The analysis is performed using scanning electron microscopy, X-ray diffraction, and Vickers hardness tests. The results show that all five metal oxide additives can reduce the hardness of carbonized products. The relative effect of reducing the coked hardness is as follows: $\mathrm{MgO}>\mathrm{CaO}>$ kaolin $>\mathrm{Fe}_{2} \mathrm{O}_{3}>\mathrm{Al}_{2} \mathrm{O}_{3}$. Thus, the effect of $\mathrm{MgO}$ on reducing the coking hardness is stronger than that of the other four metal oxides, reducing the hardness of carbonized products by approximately $81 \%$. Furthermore, the adding charge can reduce the hardness index by at least $60 \%$. When the carbonization temperature is higher than $800^{\circ} \mathrm{C}$, the hardness index of the carbonized product decreases by approximately $5 \%$ each $50^{\circ} \mathrm{C}$ of increase in temperature. This study shows that the addition of metal oxides can effectively reduce the hardness of coking during the treatment of high-salt organic wastewater by carbonization and oxidation and provide theoretical support for the subsequent treatment of high-salt organic wastewater by carbonization and oxidation.
\end{abstract}

\section{Introduction}

Domestic sewage, industrial wastewater, and other useless water, such as the inflow of the first rain path into the drainage pipes canals, are called wastewater. The direct discharge of wastewater can substantially damage the environment due to its complex composition. According to data from the China Environmental Statistics Yearbook, although the discharge of industrial wastewater in China showed a downward trend in the past decade, by 2018 , the industrial wastewater discharge in China was still high, 18.16 billion tons, accounting for $23.55 \%$ of the national wastewater discharge. Industrial wastewater is characterized by having a wide range of sources, high salt concentrations, and complex components [1-3]. A report predicted that in 2025, China would produce more than 12 million tons [4] of recoverable resources from industrial wastewater, producing over $10 \mathrm{mil}$ lion tons of waste salt. The recovery and use of the waste salt from high-salinity organic wastewater, as industrial salt, represent a major source for reuse and circular economy. Therefore, the treatment of high-salinity organic wastewater is of paramount importance.

A large number of salts and other impurities are often present in hypersaline organic wastewater. When this water is treated in a high-temperature process such as incineration $[5,6]$, pyrolysis [7], and advanced oxidation processes [8], the water can cause problems such as high hardness index coking owing to adhesion between the salt and impurity in the organic wastewater. Currently, some treatment methods such as biological [9-12] and electrodialysis methods [1315] allow treating the organic wastewater without requiring high temperatures. Moreover, these methods did not 
produce products with a high coking hardness index. However, these methods show limitations. The existing methods for treating hypersaline organic wastewater have their own advantages and disadvantages. During the process of incineration and pyrolysis, water in high-salinity organic wastewater is heated to evaporate and vaporize, separating saline water. Moreover, for the recovery of high-temperature flue gas generated in the treatment process, a method of adding an eternal magnetic field [16] or adopting a nanofluid medium [17] can be adopted to improve the waste heat recovery efficiency. The precipitation of soluble salts and the separation of heavy metals from hypersaline organic wastewater were performed using the incineration method proposed by Atanes et al. [18]. This is a simple and efficient process in wastewater treatment technology; thus, incineration is becoming a good alternative for industrialization. However, this method will cause problems such as material surface softening and equipment sticking due to uneven heating. Recently, Xie et al. [19] used the molten salt oxidation method to carbonize organic matter in waste liquid, separating the organic matter and salt separated carefully. The inherent ability of molten salt oxidation as an advanced oxidation technology is to destroy the organic components of waste while retaining inorganic components in the molten salts [20]. Lin et al. [21] showed that the waste liquid could be effectively oxidized in a molten salt bath. The temperature of molten carbonate plays a crucial role in the oxidizing process. When the temperature increased from $600^{\circ} \mathrm{C}$ to $750^{\circ} \mathrm{C}$, the oxidation efficiency increased from $91.1 \%$ to $98.3 \%$. Moreover, the influence of the air factor on the composition of the molten carbonate and the type of feed pipe was smaller than that of the temperature; the chlorine retention efficiency of molten carbonate was above $99.9 \%$. They also found that when using molten salt oxidation of waste printed circuit boards [22], more than 95\% of the copper was recycled, as the major component of ash, glass fiber is dissolved by molten carbonate and retained in the salt bath, obtaining an effective resource recovery.

Furthermore, biological methods have advantages such as low cost and wide application scope. In this regard, halophilic bacteria or salt-tolerant bacteria in sewage treatment processes could increase the salt content in wastewater or reduce the organic matter in wastewater. Some studies have shown that when the salt concentration is $10 \mathrm{mg} / \mathrm{L}$, the COD removal rate becomes the highest [23]. However, if the salt concentration is very high or contains toxic components, the growth of microorganisms will be inhibited, affecting its treatment capacity and effectiveness. Wiśniewski [24] used an anion exchange membrane to remove bromate from waste salt during the Donnan dialysis process, and dechlorinated waste during the incineration process to reduce the damage to the environment of chloride ions [25]. The electrodialysis method can only remove acid radicals from high-salinity organic wastewater; however, it cannot achieve resource utilization.

In this study, the carbonization-oxidation method was used to treat organic wastewater with high salinity. According to the difference between the carbonization point of the organic substances in wastewater and the melting point of salt, the organic substances were carbonized. Subsequently, the carbonized product was dissolved to separate the carbon and salt. Unlike the molten salt oxidation method, the carbonization oxidation method can extract organic matter from wastewater and reuse it as an industrial raw material. Similar to fused salt oxidation, inorganic salts easily agglomerate with raw materials in the wastewater during carbonization and oxidation, resulting in partial loss of salt and a lower conversion rate of salt.

In conclusion, few studies have considered adding metal oxides to reduce the coking of carbonization products formed during the carbonization of high-salt organic waste liquid. In this study, five varieties of metal oxides $\left(\mathrm{CaO}, \mathrm{MgO}, \mathrm{Fe}_{2} \mathrm{O}_{3}\right.$, $\mathrm{Al}_{2} \mathrm{O}_{3} \cdot 2 \mathrm{SiO}_{2} \cdot \mathrm{H}_{2} \mathrm{O}$, and $\mathrm{Al}_{2} \mathrm{O}_{3}$ ) and shale ash (solid waste) were added to the furnace charge. The coking structures were analyzed under different conditions using X-ray diffraction (SEM) and scanning electron microscopy (XRD). The effects of $\mathrm{CaO}, \mathrm{MgO}, \mathrm{Fe}_{2} \mathrm{O}_{3}$, kaolin $\left(\mathrm{Al}_{2} \mathrm{O}_{3} \cdot 2 \mathrm{SiO}_{2} \cdot \mathrm{H}_{2} \mathrm{O}\right)$, and $\mathrm{Al}_{2} \mathrm{O}_{3}$ on the hardness index of the carbonized products and the effect of reducing the hardness of coke were also studied. The adequate additive and proportion, as well as the temperature, could be determined through the experiment. Therefore, this study can provide theoretical support for the subsequent carbonization-oxidation method to deal with high-salinity organic wastewater.

\section{Materials and Methods}

2.1. Materials. In this study, $1 \%$ toluene, $2 \%$ benzene, and $2 \%$ mixed xylene were added to a $10 \% \mathrm{NaCl}$ solution to simulate high-salinity organic wastewater according to engineering specifications. Before the experiments, the quartz sand and shale ash were crushed to 40-60 mesh, washed with deionized water, and dried in a blast dryer at $110^{\circ} \mathrm{C}$ for $12 \mathrm{~h}$.

In the experiment, the metal oxide additives were $\mathrm{CaO}$, $\mathrm{MgO}, \mathrm{Fe}_{2} \mathrm{O}_{3}$, kaolin, and $\mathrm{Al}_{2} \mathrm{O}_{3}$; their melting points are above $1500^{\circ} \mathrm{C}$. Table 1 shows the elemental analysis of the burden, considering the quartz sand and shale ash as the burden.

2.2. Equipment and Methods. The samples were heated in a muffle furnace (HY-1000MC) and dehydrated in a blast oven. Sodium chloride, furnace charge, and additives were weighed with a precise balance with an accuracy of $0.1 \mathrm{mg}$ for accurate development of the experiment. An ultrasonic vibrator was used to thoroughly mix the sodium chloride, furnace charge, and additives. The hardness index (SII) of the carbonized products was measured using a Vickers hardness tester, and the coke after heating was tested by electron $\mathrm{X}$-ray diffraction (XRD) and scanning electron microscopy (SEM) using a TD-3500 X-ray diffractometer and an electron microscope. The detailed experimental steps are shown in Table 2.

2.3. Identification Methods. The hardness of the carbonized product was evaluated using the hardness index SII. After the experiment, the hardness of the carbonized products was calculated using a Vickers hardness tester to develop a quantitative comparison. During the experiment, under the action of a particular load, an indentation with a square cone 
TABLE 1: Elemental analysis of quartz sand and shale ash.

\begin{tabular}{lcccccccc}
\hline $\begin{array}{l}\text { Analyzed } \\
\text { element }\end{array}$ & $\mathrm{O}$ & $\mathrm{Na}$ & $\mathrm{Mg}$ & $\mathrm{Al}$ & $\mathrm{Si}$ & $\mathrm{P}$ & $\mathrm{Fe}$ & Others \\
\hline Quartz sand & 55.9 & 0.03 & - & 0.19 & 43.81 & - & 0.03 & 0.04 \\
Shale ash & 45 & - & 1.42 & 12.28 & 27.13 & 1.27 & 7.19 & 5.71 \\
\hline
\end{tabular}

Note: “-" indicates that no such element is present in the tested component.

shape was created on the surface of the sample. The diagonal length of the indentation was measured to calculate the surface area of the indentation. The value of the load divided by the surface area represents the hardness of the sample. The calculation equation presented in [26] is written as follows:

$$
H V=0.102 \times \frac{2 F \sin 136 / 2}{d^{2}} \approx 0.1891 \frac{F}{d^{2}},
$$

where $F$ is the test force $(\mathrm{N})$, and $d$ is the arithmetic mean of the diagonal lengths $d_{1}$ and $d_{2}$ of the two indentations (mm).

\section{Results and Discussion}

3.1. Effect and Mechanism of Metal Oxide Additives. In each experiment, equal volumes of the developed hypersaline organic wastewater were added to different beakers. The quantity of the metal oxide additive was added to the beaker. The additive was added using a 1:1 molar mass ratio of the cation in the metal oxide to $\mathrm{Na}+$ in the high-salt organic wastewater. The amount of the furnace charge was added to the beaker. The amount was added using a 1:1 mass ratio of the furnace charge to $\mathrm{NaCl}$ in the organic wastewater. After drying, the samples were heated in a corundum crucible, away from the door of the muffle furnace. After setting the temperature of the muffle furnace at $900^{\circ} \mathrm{C}$ for $30 \mathrm{~min}$, the samples were carbonized after drying treatment. Figure 1 shows the relationship between the hardness index, measured after carbonization, and the different types of additives.

The hardness index directly reflects the coking effect of carbonized products. Figure 1 shows that when the same quality of shale ash and quartz sand is added into the two groups of high-salinity organic wastewater, and no metal oxide additives are added, the hardness index of the carbonated product is 4.2 and 4.4. Moreover, after adding $\mathrm{CaO}$, $\mathrm{MgO}, \mathrm{Fe}_{2} \mathrm{O}_{3}$, kaolin, or $\mathrm{Al}_{2} \mathrm{O}_{3}$, the hardness index of the high-salinity organic wastewater is reduced by at least $25 \%$. Among them, the addition of $\mathrm{MgO}$ and $\mathrm{CaO}$ significantly reduced the hardness index of the product by $63.6 \%$ and $43.2 \%$, respectively. The relative effects of the five metal oxides on the hardness index of carbonized products were $\mathrm{Al}_{2} \mathrm{O}_{3}<$ kaolin $<\mathrm{Fe}_{2} \mathrm{O}_{3}<\mathrm{CaO}<\mathrm{MgO}$.

SEM and XRD enabled to observe the microstructure of the carbonized products to understand how metal oxide additives affect carbonized products of organic wastewater with high salinity. The specific analysis is discussed in the following paragraphs.
Figure 2 shows the microscopic morphology of the carbonized product of high-salt organic wastewater. In the absence of additives, the surface of the carbonized product is a polyhedral crystalline block, the surface is smooth without pores, and the edges and corners are clearly visible. In the experiment, no granular $\mathrm{NaCl}$ was present in the residual carbonization product. However, a crystalline substance was formed, which was attached to the bottom of the corundum crucible, caused by the mutual bonding of the quartz sand particles with the charge after melting [21]. After adding $\mathrm{CaO}$, the edges and corners of the carbonized product vanished, and a large amount of particulate matter was formed on the surface. A small amount of molten $\mathrm{NaCl}$ was still present in the residual slag sample. Because $\mathrm{CaO}$ encapsulated the low-melting eutectic, a layer similar to a refractory material was formed on the surface of the residual slag sample. Moreover, the substance did not have cohesiveness; thus, it reduced the mutual adhesion of molten $\mathrm{NaCl}$ and furnace charge [22]. After adding $\mathrm{MgO}$ to the high-salinity organic wastewater, the surface of the carbonized product became rough to form several pores. Moreover, powdery substances were present on the surface, as well as more loose flocculent fillers between the carbonized products. The high melting point of $\mathrm{MgO}$ powder provided a dilution effect on the molten $\mathrm{NaCl}$ and formed a protective layer on the surface of the charged particles. In addition, the presence of flocculent fillers prevented the diffusion of molten $\mathrm{NaCl}$ and adsorbed more $\mathrm{NaCl}$ instead of further diffusing on the surface of the charged particles. After adding $\mathrm{Fe}_{2} \mathrm{O}_{3}$, the surface of the carbonized product becomes rough, but there is still obvious coking. After adding kaolin and $\mathrm{Al}_{2} \mathrm{O}_{3}$, the microscopic morphology of the carbonized products is similar. The surface of the charged particles was smooth, and the edges and corners were clear. Large gaps between the particles with no flocculent filler were observed. Moreover, less $\mathrm{NaCl}$ was present on the surface of the carbonized product in the molten state, which was because $\mathrm{Al}^{3+}$ and $\mathrm{Si}^{4+}$ are having similar ionic interaction forces with molten $\mathrm{Na}^{+}$, resulting in a similar degree of sintering on the particle surface [23].

The XRD analysis chart of the high-salinity organicwastewater carbonized products is shown in Figure 3. No chemical reaction occurred in the process of heating and carbonization of the samples without any additional additives. Moreover, only $\mathrm{NaCl}$ was present in the carbonized products. Typically, sodium chloride and silicon oxide react as follows [27]:

$$
2 \mathrm{NaCl}+3 \mathrm{SiO}_{2}+\mathrm{H}_{2} \mathrm{O}=2 \mathrm{HCl}+\mathrm{Na}_{2} \mathrm{O}+3 \mathrm{SiO}_{2}
$$

However, the chemical reaction between sodium chloride and silicon oxide did not occur because the sample was dried in a blast dryer before heating, and no additional water was added to the chemical reaction. This shows that only the physical reaction of $\mathrm{NaCl}$ occurred during the heating process. After adding $\mathrm{CaO}$, the XRD analysis diagram of the carbonized products showed that only two crystal phases were present, $\mathrm{CaO}$ and $\mathrm{NaCl}$, in the carbonized products, and no material with a high melting point was generated by the reaction between sodium silicate and $\mathrm{CaO}$ [28]. This again shows 
TABLE 2: The experimental steps.

\begin{tabular}{|c|c|}
\hline Order & Step \\
\hline 1 & Number the beakers and add the charge and additives as required. \\
\hline 2 & Adding an organic solution of sodium chloride prepared by using deionized water into a beaker. \\
\hline 3 & The beaker was stirred thoroughly and placed in an ultrasonic vibrator for 2 hours. \\
\hline 4 & $\begin{array}{l}\text { After completely mixing the } \mathrm{NaCl} \text { in the beaker, the furnace charge, and the additive, the mixture was dried in a blast dryer at a } \\
\text { temperature of } 120^{\circ} \mathrm{C} \text { for } 4 \text { hours. }\end{array}$ \\
\hline 5 & $\begin{array}{l}\text { Lay the dried sample on the bottom of the corundum crucible with a thickness of more than } 5 \mathrm{~mm} \text {, blow the crucible with nitrogen, } \\
\text { cover the crucible, and heat it in a muffle furnace far away from the box door. The temperature shall be subjected to the requirements } \\
\text { of the experimental group. }\end{array}$ \\
\hline 6 & $\begin{array}{l}\text { After being heated for } 30 \text { minutes, the samples were extracted to conduct the hardness test or SEM, and the experimental data were } \\
\text { recorded. }\end{array}$ \\
\hline 7 & Repeat the experiment three times and to obtain the average value. \\
\hline
\end{tabular}

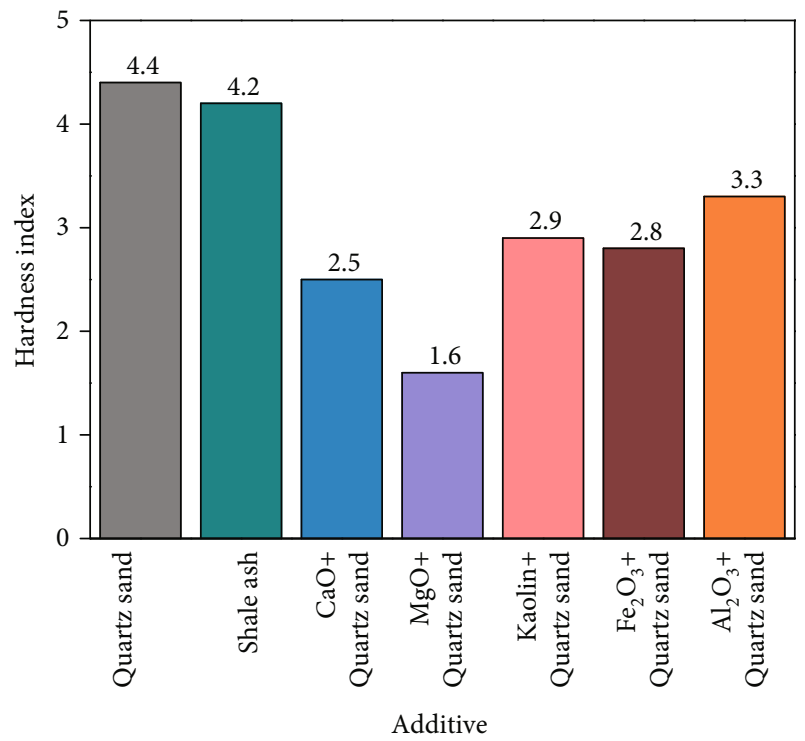

FIGURE 1: Effect of metal oxide additives on hardness index.

that the main mechanism of the coking of carbonized products is not a chemical reaction but a physical action. A high-melting-point $\mathrm{CaO}$ powder produces a dilution effect on molten $\mathrm{NaCl}$, forming a protective layer on the surface of charged particles to prevent the molten $\mathrm{NaCl}$ powder from sticking to the particles to restrain coking. With the addition of $\mathrm{MgO}$, only two crystalline phases of $\mathrm{MgO}$ and $\mathrm{NaCl}$ are present in the carbonized products, and the detectable intensity of $\mathrm{NaCl}$ clearly decreases. The flocculent filler formed by $\mathrm{MgO}$ on the surface of the carbonized products absorbed $\mathrm{NaCl}$ so that the amount of $\mathrm{NaCl}$ existing on the surface of the carbonated products substantially decreased. The XRD results of the carbonization products were similar after adding $\mathrm{Fe}_{2} \mathrm{O}_{3}$, kaolinite, or $\mathrm{Al}_{2} \mathrm{O}_{3}$, indicating that the three kinds of metal oxides had similar mechanisms to inhibit the coking of the carbonization products.

The results of SEM and XRD show that the metal oxide mechanism reduces the coking of the carbonized product, as shown in Figure 4. In particular, Figure 4(a) shows that when the high-salt organic wastewater is not carbonized with metal oxide after the furnace charge adheres to the surface of $\mathrm{NaCl}$, the furnace charge adheres to each other. Moreover, the particles after the carbonization of organic matter adhere to each other, forming coking. As shown in Figure 4(b), the added additives adhere to the burden surface and form a protective layer; the organic matter carbonated particles and the burden are no longer bond with $\mathrm{NaCl}$.

In this experiment, because the $\mathrm{CaO}$ wraps the lowmelting-point eutectic, a layer of refractory-like material was formed on the surface of the residual slag sample, and the material was not cohesive, thus, reducing the bonding between the molten $\mathrm{NaCl}$ and the furnace charge [22]. After adding the $\mathrm{MgO}$, the high-melting-point $\mathrm{MgO}$ powder could dilute the molten $\mathrm{NaCl}$ and formed a protective layer on the surface of the charged particles. Besides, the presence of flocculent filler could prevent the diffusion of molten $\mathrm{NaCl}$ better, and more $\mathrm{NaCl}$ was absorbed instead of further diffusing on the surface of the furnace charge particles. After adding $\mathrm{Fe}_{2} \mathrm{O}_{3}$, kaolin, and $\mathrm{Al}_{2} \mathrm{O}_{3}$, the microstructures of the carbonized products were similar. Moreover, a slightly molten state of $\mathrm{NaCl}$ remains on the surface of the carbonized products. This may be because the $\mathrm{Fe}^{3+}$ and $\mathrm{Al}^{3+}$ are positive trivalent cations, having similar interaction force with molten $\mathrm{Na}^{+}$, resulting in a similar sintering degree on the surface of the particles [23]. After $\mathrm{Fe}_{2} \mathrm{O}_{3}$, kaolin, and $\mathrm{Al}_{2} \mathrm{O}_{3}$ were added, the surfaces of the burden particles were smooth with clear edges and corners, with larger gaps between the particles. This indicates that the three additives may play a role in the framework for melting the ash melt, effectively raising the melting point of the eutectic to inhibit coking [29].

From the above results, owing to the protective effect of the furnace charge due to the additive, the $\mathrm{NaCl}$ adhered to the surface of the carbonized product was reduced, and more $\mathrm{NaCl}$ was separated; thus, the conversion rate of waste salt increased.

3.2. Effect of Additive Types. In the following experiment, the quartz sand considered in the previous section was replaced by shale ash with the same quality, and the remaining conditions remained unchanged. The hardness indexes of the carbonized products were measured after the experiment. Figure 5 shows the effect of metal oxide additives on the hardness index. 


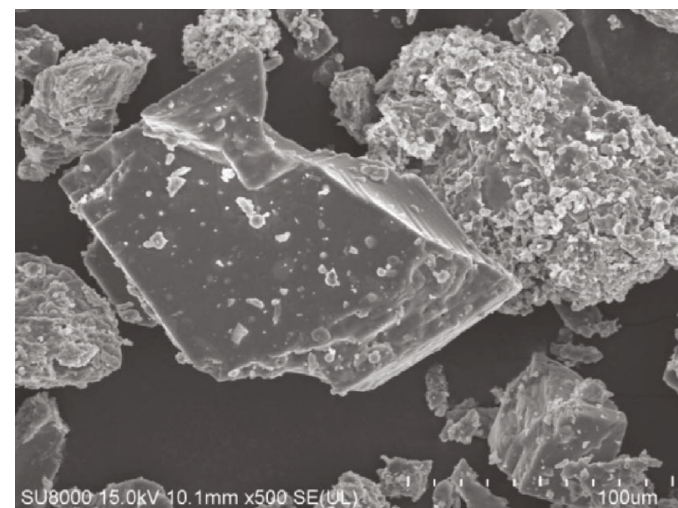

(a)

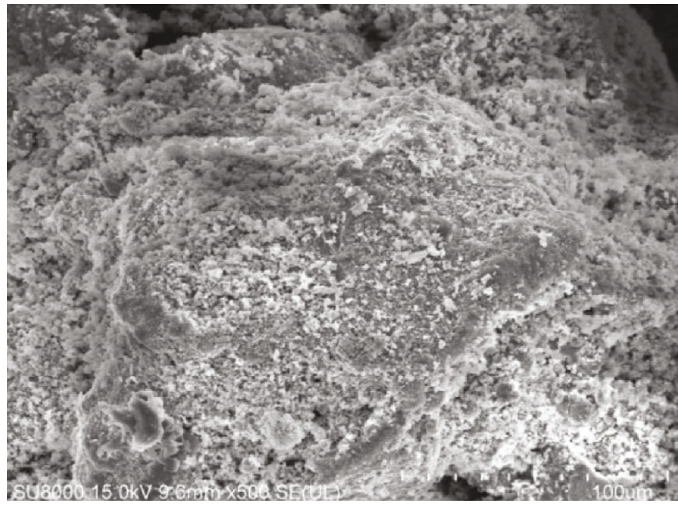

(c)

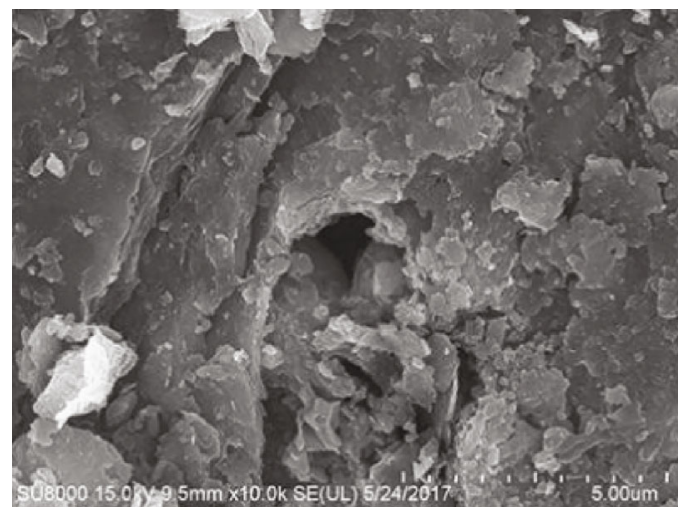

(e)

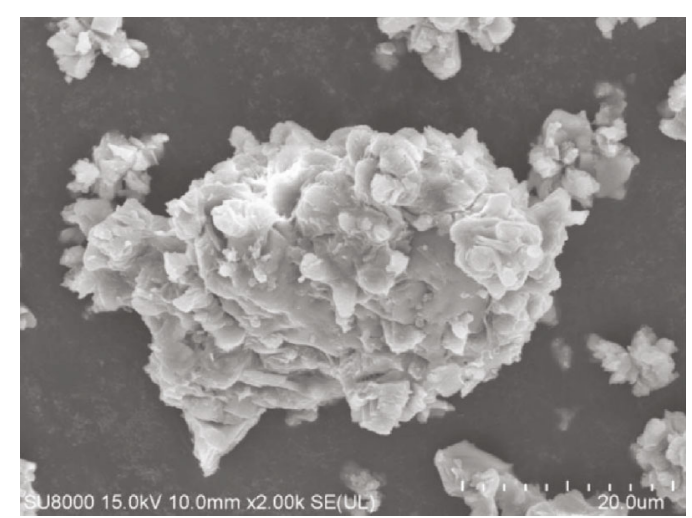

(b)

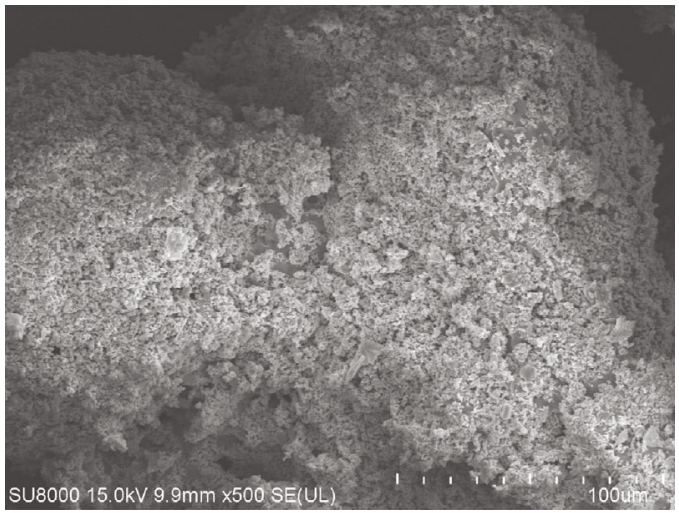

(d)

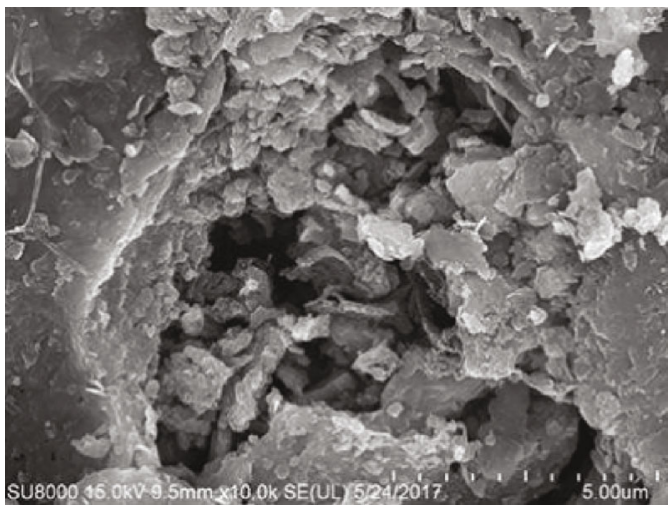

(f)

Figure 2: Microstructure of carbonization products. (a) No additions. (b) $\mathrm{CaO}$. (c) $\mathrm{MgO}$ (d) $\mathrm{Fe}_{2} \mathrm{O}_{3}$. (e) $\mathrm{Kaolin}$ (f) $\mathrm{Al}_{2} \mathrm{O}_{3}$.

Figure 4 shows that the hardness indexes of the carbonization products of the high-salt organic wastewater are 4.4 and 4.2 when the furnace charges are quartz sand and shale ash, respectively, without additional additives. As shown in Figure 5, the hardness index is reduced by at least $25 \%$ after adding the metal oxide additive. The hardness indexes can be reduced by $25-63.6 \%$ and $33.3-66.7 \%$ when using quartz sand and shale ash as the furnace charge, respectively. $\mathrm{MgO}$ shows a better effect on reducing the hardness index because the floccules produced by $\mathrm{MgO}$ absorb molten $\mathrm{NaCl}$. $\mathrm{Fe}_{2} \mathrm{O}_{3}$ and $\mathrm{Al}_{2} \mathrm{O}_{3}$ have no significant effect on hardness reduction because $\mathrm{Na}^{+}$in quartz sand interacts with $\mathrm{Fe}^{3+}\left(\mathrm{Fe}_{2} \mathrm{O}_{3}\right)$ and $\mathrm{Al}^{3+}\left(\mathrm{Al}_{2} \mathrm{O}_{3}\right)$ [30]. Concerning the charging, the relative effect of the five additives on the hardness index of carbonized products was $\mathrm{MgO}>\mathrm{CaO}>$ kaolin $>\mathrm{Fe}_{2} \mathrm{O}_{3}>\mathrm{Al}_{2} \mathrm{O}_{3}$. In conclusion, $\mathrm{MgO}$ is an additive that can significantly reduce the coking caused by the cohesion of molten $\mathrm{NaCl}$ and furnace charge in processing high-salinity organic wastewater by carbonization-oxidation.

3.3. Effect of Additive Ratio. Under the same conditions, different molar mass ratios of metal oxide additives $(1: 0.3$, $1: 0.6,1: 0.9,1: 1.2$, and $1: 1.8)$ were added to the organic wastewater with high salinity. The hardness indexes of the carbonized products were measured after being dried and 


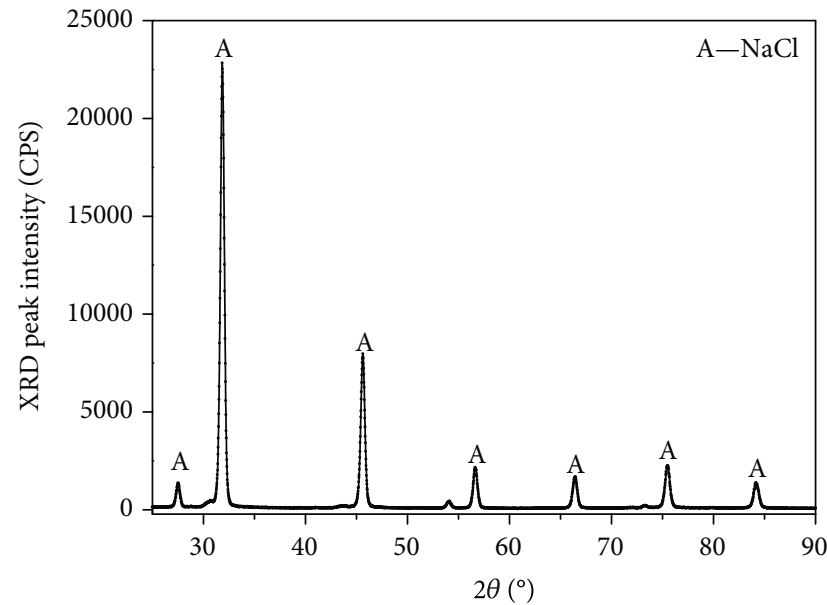

(a)

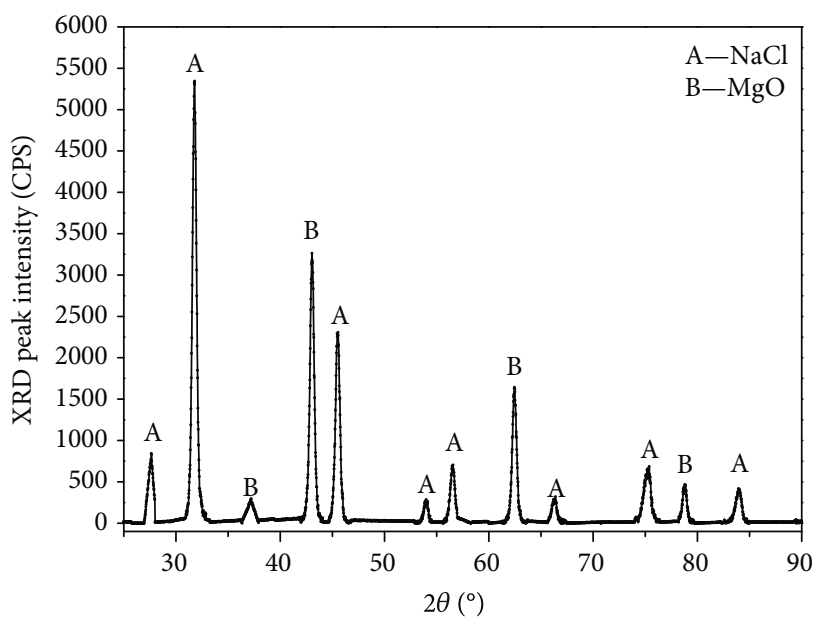

(c)

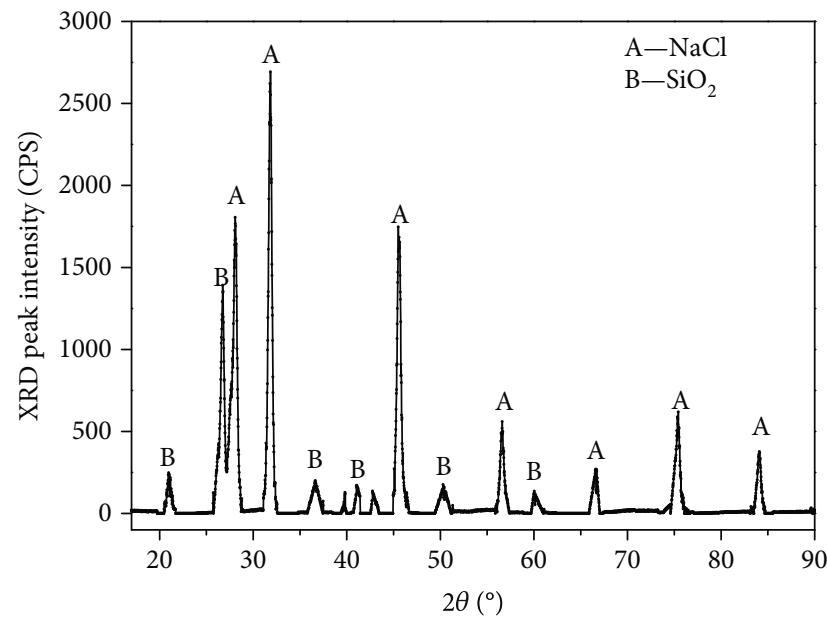

(e)

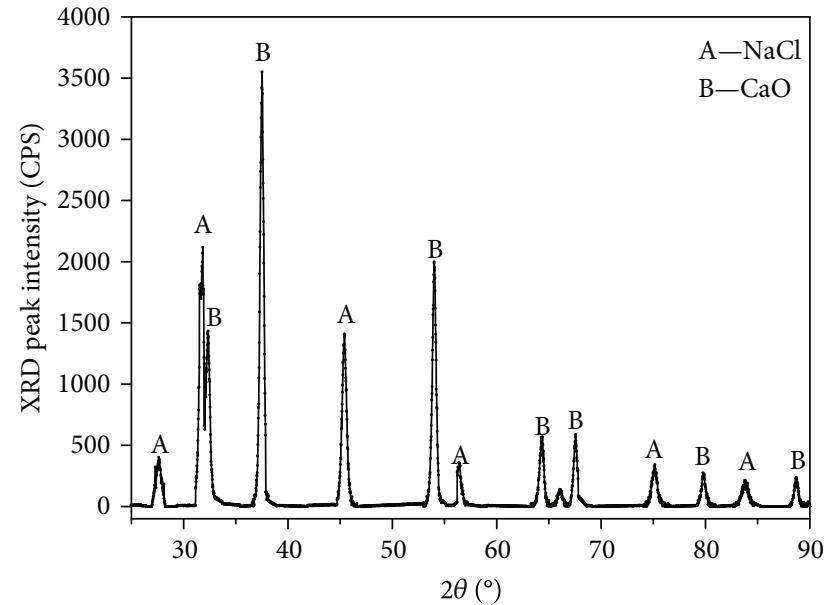

(b)

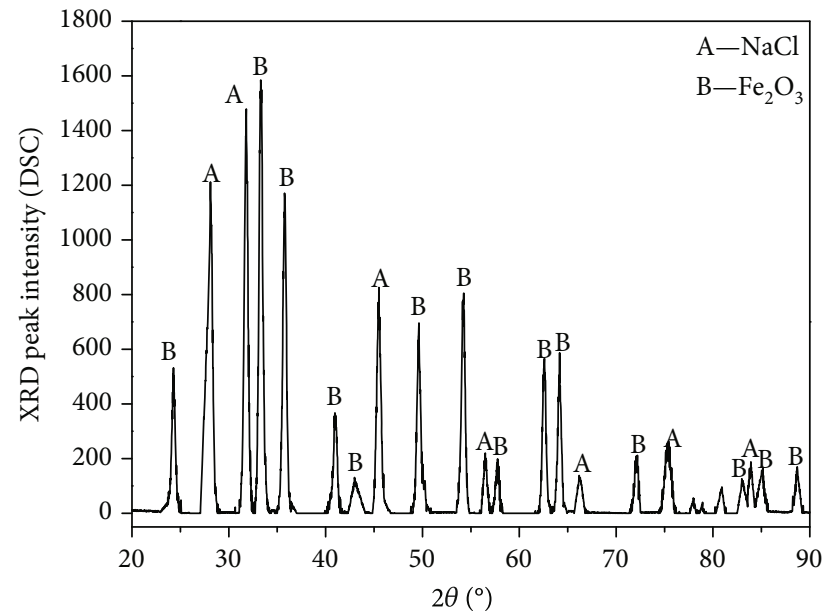

(d)

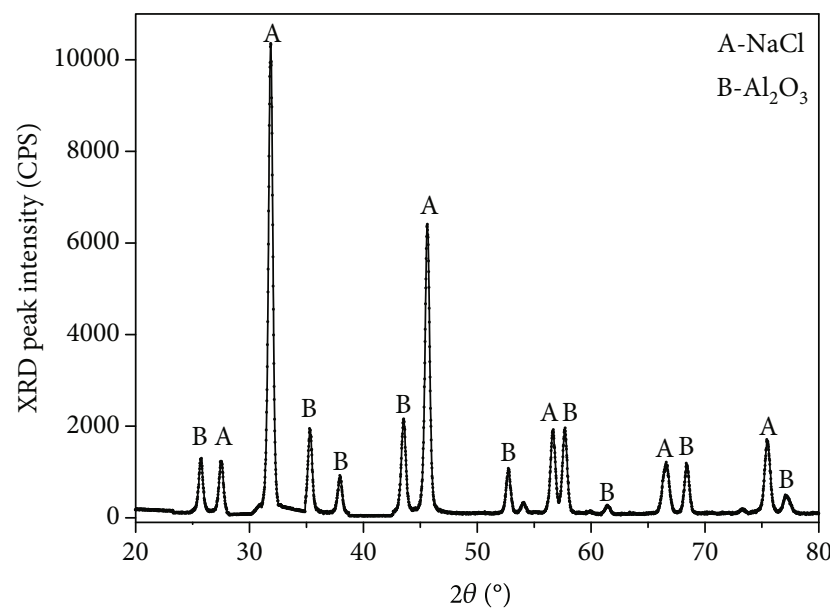

(f)

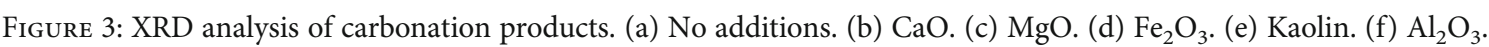

carbonized. The relationship between the measured hardness index and the ratio of the additives is shown in Figure 6.

As shown in Figure 6, when the proportion of the metal oxide additive is 0.3 , the hardness of the experimental residual slag decreases by $6.8-13.6 \%$. The effect of the additive on reducing the hardness is not significant. The hardness decreases by $70.5-81.4 \%$ when the proportion of the additives is 1.8 ; thus, significantly reducing the coking. Moreover, Figure 6 can be divided into two regions, regions A and B, according to the change rate of the hardness index to the 


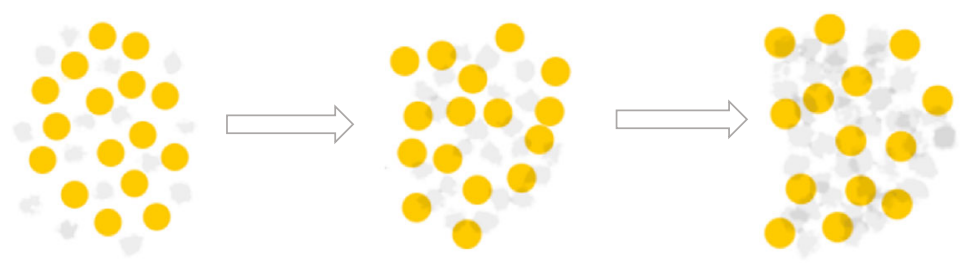

(a)
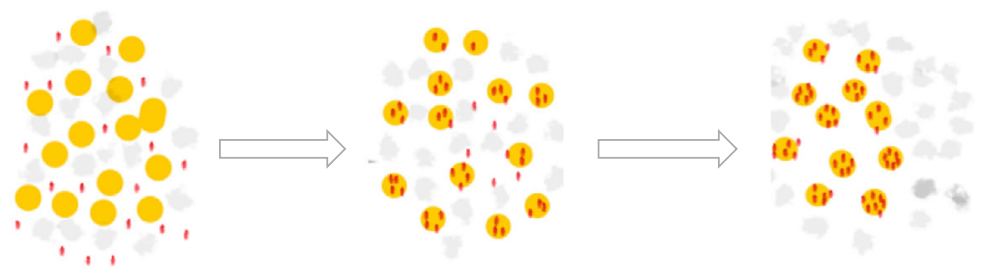

(b)

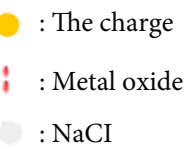

Figure 4: Schematic diagram of coking hardness reduction.

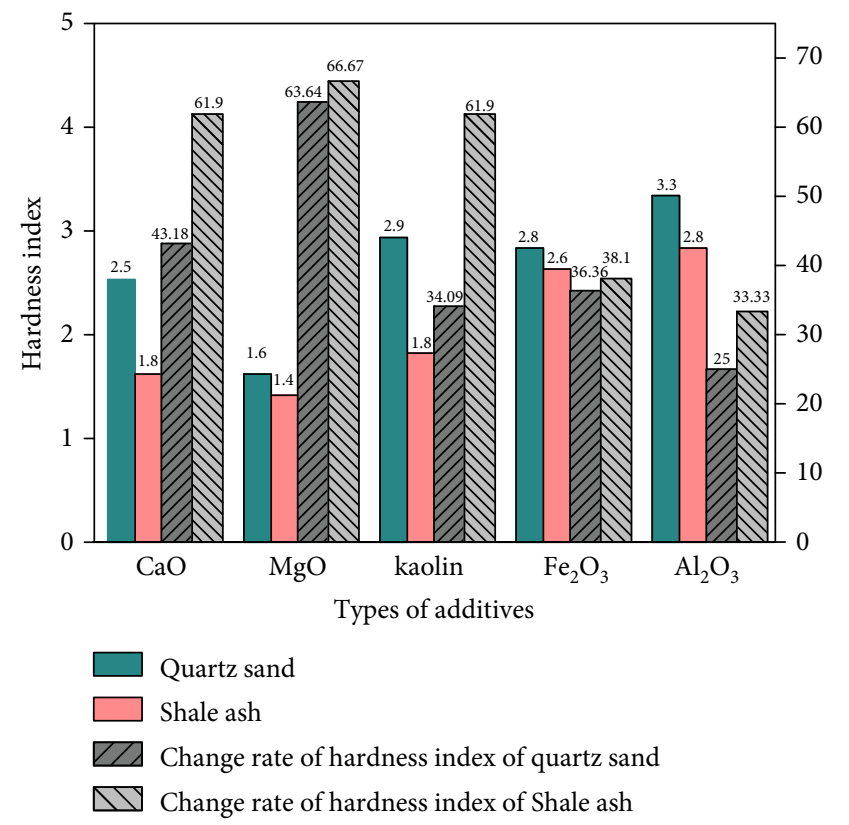

FIGURE 5: Effect of metal oxide additives on hardness index.

proportion of additives. In region $\mathrm{A}$, the hardness index of the carbonized product reduces by approximately $20 \%$ on average for every 0.3 increments of the additive proportion. In contrast, in region $\mathrm{B}$, with an increase in the additive proportion, the hardness index decrease is not evident. The hardness index of carbonized products is reduced by $6 \%$ when the additive proportion is increased every 0.3 . The reason is that the crystal protective layer formed by the additives outside the sample particles created a certain hardness in the burden. When the proportion of additives increased gradu- ally, the dilution effect of additives on $\mathrm{NaCl}$ was already large enough. No chemical reaction was present in the SEM analysis after adding additives, and the added additives could cover the furnace charge with a certain hardness. Thus, the rate of reducing the hardness index of each additive tends to be slow. Furthermore, as shown in Figure 6, the effect of preventing coking is always superior when using $\mathrm{MgO}$ as an additive. This result is similar to the microstructure analysis of the carbonized product because the flocculent produced by $\mathrm{MgO}$ adsorbs $\mathrm{NaCl}$; thus, less $\mathrm{NaCl}$ adheres to the surface of the furnace charge than the other four additives [31].

3.4. Effect of Burden and Its Proportioning. Three groups were considered based on adding different mass ratios of furnace charge $(1: 1,1: 1.3,1: 1.7,1: 2.5$, and $1: 5)$ to high-salinity organic wastewater. In the first group, no additional additive was added, and the furnace charge was shale ash. In the second group of experiments, the burden was shale ash without any additives. The third group was based on the first group of experiments, adding $\mathrm{MgO}$, whose molar mass ratio is $1: 1$. The fourth group was based on the second group of experiments; however, the same proportion of $\mathrm{MgO}$ was added, in this case. After drying, the samples were placed in a muffle furnace, and the heating conditions were consistent with the above experiments. The relationship between the hardness index and the charge and its ratio is shown in Figure 7.

Figure 7 shows the linear relationship between the type and proportion of charge and the hardness index. As shown in the figure, the hardness index of the carbonation product decreases with an increase in the proportion of the furnace charge when no additive is considered. The type and proportion of charge and the hardness index can reduce the hardness index of the carbonation product by approximately 


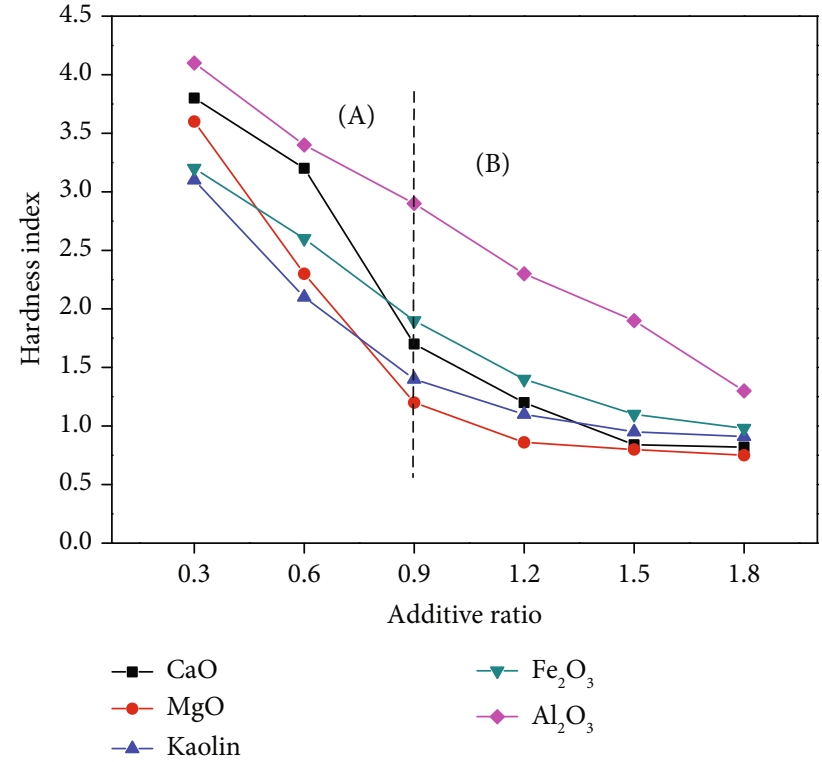

FIGURE 6: Effect of the metal oxide additives proportion on the hardness index.

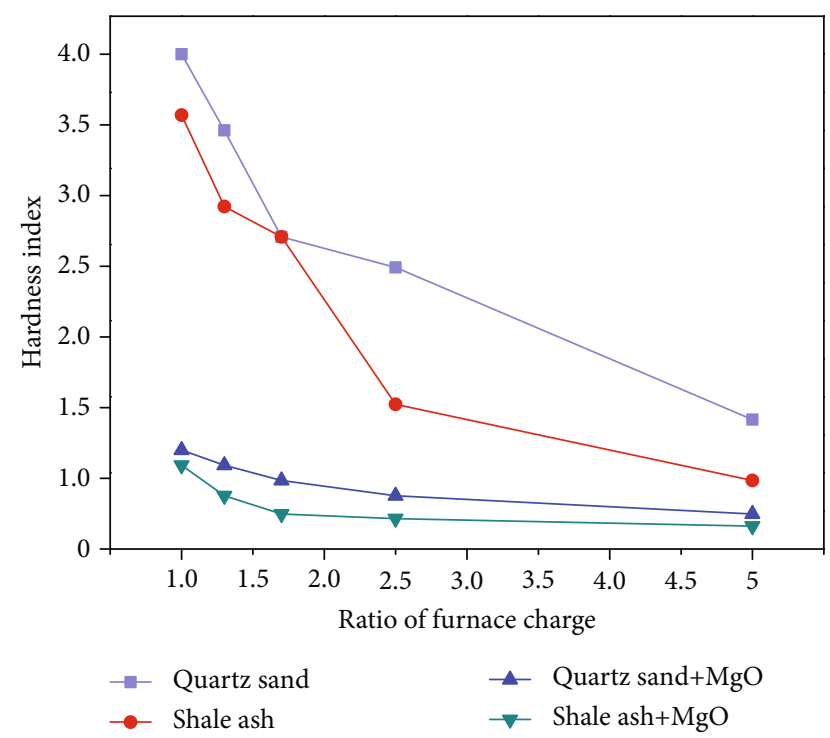

FIGURE 7: Effect of furnace charge and ratio on the hardness of carbonization products.

$60 \%$. When the burden proportion is less than 2.5 , and the proportion of the burden increases for every $50 \%$, the hardness index of the carbonation products decreases by $10 \%$ and $15 \%$ when the quartz sand and shale ash are used as the burden, respectively. When the burden proportion is above 2.5 , and the proportion of the burden increases for every $50 \%$, the hardness indexes of the carbonation products containing quartz sand and shale ash decrease by $4.5 \%$ and $2.3 \%$, respectively. Thus, the hardness of carbonized products decreases with an increase in the burden ratio, showing that the burden hinders the $\mathrm{NaCl}$ melting-induced coking [32]. As the burden proportion continuously increases because of

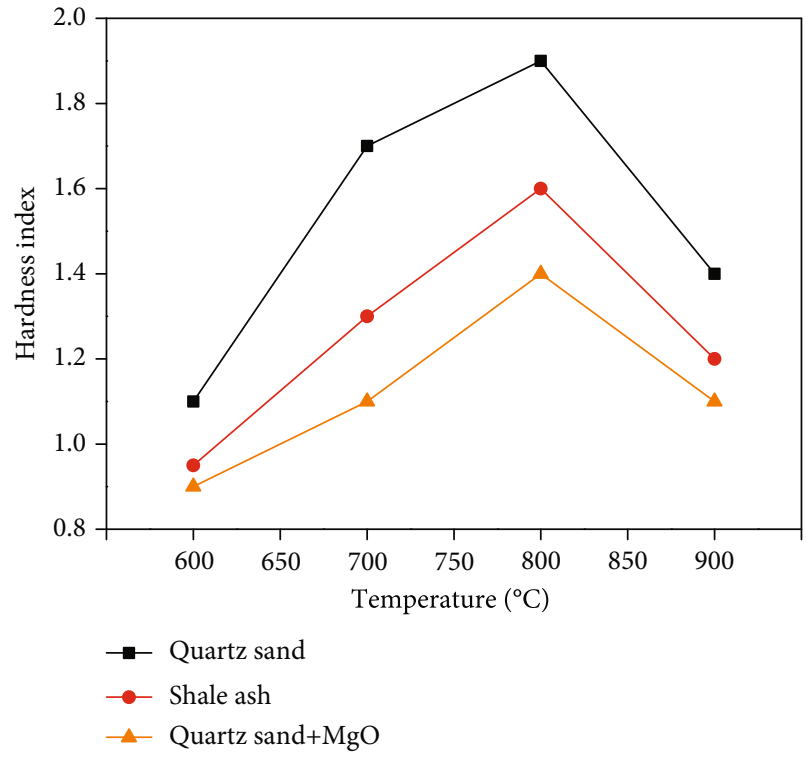

Figure 8: Effect of temperature on the hardness index.

the hardness of the burden itself, the hardness index decreases with an increase in the burden proportion. Moreover, the effect of inhibiting coking caused by the further increase in the burden ratio is no longer evident. With the addition of $\mathrm{MgO}$, the hardness index of carbide is reduced at least by $68.2 \%$, which further verified the effect of additives on the hardness reduction of carbide. In addition, the effect of shale ash on hardness reduction is stronger than that of quartz sand under the same burden addition ratio, which is related to the composition of quartz sand and shale ash [30].

3.5. Effect of Temperature. The first group of samples used quartz sand as the furnace charge, while the second group of samples used shale ash as the furnace charge, without adding additional additives. In the third group of samples, quartz sand was used as the furnace charge, and $\mathrm{MgO}$ with a molar mass ratio of $1: 1$ was added. After drying the above three groups of samples, the hardness indexes of each sample at $600^{\circ} \mathrm{C}, 700^{\circ} \mathrm{C}, 800^{\circ} \mathrm{C}$, and $900^{\circ} \mathrm{C}$ were measured, as shown in Figure 8.

Figure 8 shows that the hardness index of the carbonized products increases at first and subsequently decreases with an increase in temperature for the three experimental groups. The results show that when the temperature increases every $50^{\circ} \mathrm{C}$, the hardness index increases by $4 \%$ until $800^{\circ} \mathrm{C}$. In contrast, the hardness index decreases by approximately $5 \%$ when the temperature increases every $50^{\circ} \mathrm{C}$ for values higher than $800^{\circ} \mathrm{C}$. The reason is that the melting temperature of $\mathrm{NaCl}$ is approximately $800^{\circ} \mathrm{C}$. Therefore, when the temperature is below $800^{\circ} \mathrm{C}$, the melting degree of $\mathrm{NaCl}$ increases with increasing temperature, thus, promoting the agglomeration of carbonized products and increasing its hardness. When the temperature is above $800^{\circ} \mathrm{C}, \mathrm{NaCl}$ is in a molten state. With an increase in temperature, a small amount of $\mathrm{NaCl}$ may begin to evaporate on the surface of the carbonized product (in this process, the evaporated $\mathrm{NaCl}$ gas is not in 
molecular form), leading to an increase in the burden ratio and additive ratio. Thus, inhibiting the accumulation of carbonation products and reducing their hardness [29]. In the carbonization oxidation process of high-salt organic wastewater, the temperature can be set to above the melting point of salt to reduce the hardness of the coke.

\section{Conclusions}

The hardness index was introduced as an index to evaluate the hardness of carbonized products. The structure of the carbonized products after adding metal oxide additives was analyzed through SEM, XRD, and Vickers hardness test. The effects of the type and proportion of metal oxides, burden, and temperature on the hardness index of carbonized products were studied. The conclusions can be drawn as follows:

(1) The relationship between the metal oxide additives and the hardness index of carbonized products showed that an increase in the molar mass ratio of the additives decreases the hardness index of the carbonized products significantly. The relative effect of the five metal oxide additives on reducing hardness was $\mathrm{MgO}>\mathrm{CaO}>$ Kaolin $>\mathrm{Fe}_{2} \mathrm{O}_{3}>\mathrm{Al}_{2} \mathrm{O}_{3}$. Among them, $\mathrm{MgO}$ can reduce the hardness index by approximately $80 \%$.

(2) Burden and temperature also affect the hardness index of carbonation products. The hardness index of the carbonization products decreases with an increase in the added burden ratio. When quartz sand and shale ash were used as the furnace charge, the hardness index decreased by approximately $60 \%$ and $66 \%$, respectively. For temperatures above $800^{\circ} \mathrm{C}$, the hardness index decreased by approximately $10 \%$ for every $50^{\circ} \mathrm{C}$ increments

(3) Carbonization and oxidation technology can recycle the inorganic salts and organic matter in high-salt organic wastewater largely. This research can effectively solve the problem of coking in carbonization and oxidation treatment of wastewater. Therefore, adding metal oxide additives can increase the recovery rate of inorganic salts and organics in organic wastewater in actual industrial production. However, this study uses a laboratory to configure a mixed liquid to simulate high-salt organic wastewater and does not consider the impact of other particles in the actual wastewater. In future research, a wider range of metal oxide species should be selected, and the impact of other particles in actual industrial wastewater should be considered

\section{Data Availability}

The data used to support the findings of this study are available from the corresponding author upon request.

\section{Conflicts of Interest}

The authors declare that they have no conflicts of interest.

\section{References}

[1] S. N. Malik, P. C. Ghosh, A. N. Vaidya, and S. N. Mudliar, "Ozone pre-treatment of molasses-based biomethanated distillery wastewater for enhanced bio-composting," Journal of Environmental Management, vol. 246, pp. 42-50, 2019.

[2] W. W. Ma, Y. X. Han, C. Y. Xu et al., "Biotoxicity assessment and toxicity mechanism on coal gasification wastewater (CGW): a comparative analysis of effluent from different treatment processes," Science of The Total Environment, vol. 637638, pp. 1-8, 2018.

[3] H. B. Liu, H. N. Wang, X. Zhou, J. L. Fan, Y. F. Liu, and Y. Yang, "A comprehensive index for evaluating and enhancing effective wastewater treatment in two industrial parks in China," Journal of Cleaner Production, vol. 230, pp. 854-861, 2019.

[4] Y. Wang, X. Mei, T. F. Ma et al., "Green recovery of hazardous acetonitrile from high-salt chemical wastewater by pervaporation," Journal of Cleaner Production, vol. 197, pp. 742-749, 2018.

[5] M. K. Lee and S. Kang, "A study of salt-assisted solution combustion synthesis of magnesium aluminate and sintering behaviour," Ceramics International, vol. 45, no. 6, pp. 66656672, 2019.

[6] X. D. Li, J. H. Lv, M. R. Xu, J. Y. Ma, J. H. Yan, and K. F. Cen, "Agglomeration characteristics in fluidized bed incineration of organic-condensed wastewater," Journal of Chemical Industry and Engineering (China), vol. 56, pp. 2166-2171, 2005.

[7] Y. E. Lee, J. H. Jo, I. T. Kim, and Y. S. Yoo, "Chemical characteristics and $\mathrm{NaCl}$ component behavior of biochar derived from the salty food waste by water flushing," Energies, vol. 10, no. 10, p. 1555, 2017.

[8] Y. Sun, L. L. Yu, H. B. Huang, J. W. Yang, and S. A. Cheng, "Research trend and practical development of advanced oxidation process on degradation of recalcitrant organic wastewater," Journal of Chemical Industry and Engineering (China), vol. 68, pp. 1743-1756, 2017.

[9] A. Ebrahimi, D. Y. Kebria, and G. N. Darzi, "Improving bioelectricity generation and COD removal of sewage sludge in microbial desalination cell," Environmental Technology, vol. 39, no. 9, pp. 1188-1197, 2018.

[10] M. J. Nelson, G. Nakhla, and J. Zhu, "Fluidized-bed bioreactor applications for biological wastewater treatment: a review of research and developments," Engineering, vol. 3, no. 3, pp. 330-342, 2017.

[11] H. F. Zhuang, H. J. Han, S. D. Shan, and X. D. Xue, “Advanced treatment of coal chemical wastewater using a novel MBBR process with short-cut biological nitrogen removal," Journal of Chemical Industry and Engineering (China), vol. 67, pp. 3919-3926, 2016.

[12] W. Y. Hu, Y. Zhou, X. Min et al., "The study of a pilot-scale aerobic/Fenton/anoxic/aerobic process system for the treatment of landfill leachate," Environmental Technology, vol. 39, no. 15, pp. 1926-1936, 2018.

[13] A. Luiz, D. D. McClure, K. Lim et al., "Potential upgrading of bio-refinery streams by electrodialysis," Desalination, vol. 415 , pp. 20-28, 2017. 
[14] B. Pisarska, H. Jaroszek, W. Mikołajczak et al., "Application of electro-electrodialysis for processing of sodium sulphate waste solutions containing organic compounds: preliminary study," Journal of Cleaner Production, vol. 142, pp. 3741-3747, 2017.

[15] S. G. Le Han and H. R.-d. Balmann, "Transfer of neutral organic solutes during desalination by electrodialysis: Influence of the salt composition," Journal of Membrane Science, vol. 511, pp. 207-218, 2016.

[16] J. Wang, G. Li, H. Zhu, J. Luo, and B. Sundén, "Experimental investigation on convective heat transfer of ferrofluids inside a pipe under various magnet orientations," International Journal of Heat and Mass Transfer, vol. 132, pp. 407-419, 2019.

[17] D. Zheng, J. Wang, Z. X. Chen, J. Baleta, and B. Sundén, "Performance analysis of a plate heat exchanger using various nanofluids," International Journal of Heat and Mass Transfer, vol. 158, pp. 11-21, 2020.

[18] E. Atanes, B. Cuesta-Garcia, A. Nieto-Marquez, and F. Fernandez-Martinez, "A mixed separation-immobilization method for soluble salts removal and stabilization of heavy metals in municipal solid waste incineration fly ash," Journal of Environmental Management, vol. 240, pp. 359-367, 2019.

[19] K. Xie, H. Hu, J. Cao, F. Yang, and H. Yao, “A novel method for salts removal from municipal solid waste incineration fly ash through the molten salt thermal treatment," Chemosphere, vol. 241, article 125107, 2019.

[20] T. L. Guggenheim, L. M. Kloppenburg, and C. Poirier, "Purification and utilization of a formerly incinerated sodium nitrite bearing wastewater stream," Green Processing and Synthesis, vol. 2, pp. 311-322, 2013.

[21] C. Lin, Y. Chi, Y. Jin et al., "Molten salt oxidation of organic hazardous waste with high salt content," Waste Management and Research, vol. 36, no. 2, pp. 140-148, 2018.

[22] C. Lin, C. Yong, and Y. Jin, "Experimental study on treating waste printed circuit boards by molten salt oxidation," Waste and Biomass Valorization, vol. 8, no. 7, pp. 2523-2533, 2017.

[23] S. Aslan and N. Sekerdag, "Salt inhibition on anaerobic treatment of high salinity wastewater by upflow anaerobic sludge blanket (UASB) reactor," Desalination and Water Treatment, vol. 57, pp. 12998-13004, 2015.

[24] J. A. Wiśniewski, M. Kabsch-Korbutowicz, and S. Łakomska, "Ion-exchange membrane processes for $\mathrm{Br}^{-}$and $\mathrm{BrO}^{3-}$ ion removal from water and for recovery of salt from waste solution," Desalination, vol. 342, pp. 175-182, 2014.

[25] S. Dai, Y. Zheng, Y. Zhao, Y. Chen, and D. Niu, "Molten hydroxide for detoxification of chlorine-containing waste: unraveling chlorine retention efficiency and chlorine salt enrichment," Journal of Environmental Sciences, vol. 82, pp. 192-202, 2019.

[26] I. Hervas, A. Montagne, A. Van Gorp, M. Bentoumi, A. Thuault, and A. Iost, "Fracture toughness of glasses and hydroxyapatite: a comparative study of 7 methods by using Vickers indenter," Ceramics International, vol. 42, no. 11, pp. 12740-12750, 2016.

[27] P. Acharya, "Process challenges and evaluation of bed agglomeration in a circulating bed combustion system incinerating red water," Environmental Progress, vol. 16, no. 1, pp. 54-64, 1997.

[28] S. F. Corsino, M. Capodici, M. Torregrossa, and G. Viviani, “A comprehensive comparison between halophilic granular and flocculent sludge in withstanding short and long-term salinity fluctuations," Journal of Water Process Engineering, vol. 22, pp. 265-275, 2018.
[29] L. G. Xu, Y. J. Huang, J. Wang, L. Zou, and J. F. Yue, "Hightemperature corrosion properties of water wall material $15 \mathrm{CrMoG}$ under reducing atmosphere," Journal of ZheJiang University (Engineering Science), vol. 52, pp. 1535-1541, 2018.

[30] B. Mysen and D. Virgo, "Volatiles in silicate melts at high pressure and temperature: 2. Water in melts along the join NaAlO," Chemical Geology, vol. 57, no. 3-4, pp. 333-358, 1986.

[31] Y. S. Li, Y. F. Duan, M. Liu, N. Li, C. Chen, and J. H. Lv, "Reaction parameters and mechanism of flocculent multifunction polyphenylene sulfide filter," China Environmental Science, vol. 39, pp. 2344-2353, 2019.

[32] E. Mousa, D. Senk, and A. Babich, "Reduction of pellets-nut coke mixture under simulating blast furnace conditions," Steel Research International, vol. 81, no. 9, pp. 706-715, 2010. 